\title{
西双版纳热带山地雨林的植物多样性研究
}

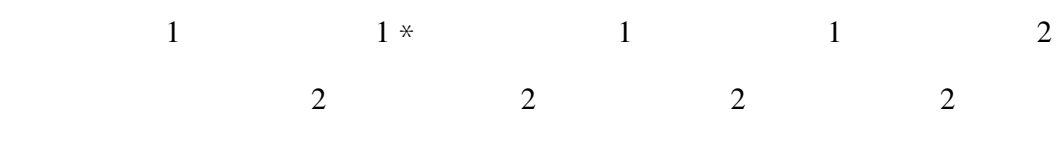

(1 中国科学院西双版纳热带植物园热带雨林生态系统定位研究站, 云南预腊 666303)

(2 西双版纳国家级自然保护区管理局, 云南景洪 666300)

\begin{abstract}
摘 要 根据 6 块样地的调查资料, 分析了西双版纳热带山地雨林植物多样性特征。结果表明: 在 $2500 \mathrm{~m}^{2}$ 的样地 上, 西双版纳热带山地雨林群落共有植物物种 99 181 种。其中乔木层的物种丰富度 $(S)$ 为 $54 \sim 113$, ShannonWiener 指数 $\left(H^{\prime}\right)$ 为 $1.6487 \sim 4.0491$, Simpson 指数 $(\lambda)$ 为 $0.5035 \sim 0.9695$, Pielou 均匀度指数 $\left(J_{\text {sw }}\right)$ 为 $0.4133 \sim$ 0.8549 。灌木层的 $S$ 为 $35 \sim 89, H^{\prime}$ 为 $2.4132 \sim 3.7162, \lambda$ 为 $0.7627 \sim 0.9582, J_{\mathrm{sw}}$ 为 $0.6788 \sim 0.859$ 3。草本层的各 指数值: $S$ 为 $31 \sim 65, H^{\prime}$ 为 $2.7921 \sim 3.4992, \lambda$ 为 $0.9020 \sim 0.9382, J_{\mathrm{sw}}$ 为 $0.7293 \sim 0.8382$ 。低海拔带上的山地雨 林 ( I 号、II 号样地) 的各指数值 $\left(H^{\prime} 、 \lambda 、 J_{\mathrm{sw}}\right)$ 在群落不同层次中均表现为草本层 > 灌木层 > 乔木层, 而物种丰富 度在不同层次中无一定变化规律; 高海拔带上山地雨林 ( III 号、IV 号、V 号、VI号样地) 的物种丰富度和多样性指数 $\left(H^{\prime} 、 \lambda\right)$ 表现为乔木层 > 灌木层 > 草本层, 而均匀度指数 $\left(J_{\mathrm{sw}}\right)$ 在不同层次中则无一定变化趋势。高海拔带上的 山地雨林乔木层和灌木层的物种丰富度、多样性和均匀度指数均明显高于低海拔带上的山地雨林, 这是由于前者 所处生境较为优越。沿着海拔梯度, 群落乔木层的物种丰富度、多样性和均匀度指数均在中等海拔高度地带 (约 $1200 \sim 1220 \mathrm{~m}$ )达到最高值, 这是由于中等海拔高度的山地雨林位于生境条件最为优越的沟谷地带, 而且与低地季 节雨林毗邻，热带雨林植物成分丰富。
\end{abstract}

关键词 植物多样性 热带山地雨林 西双版纳

\section{A STUDY ON PLANT DIVERSITY OF TROPICAL MONTANE RAIN FORESTS IN XISHUANGBANNA, YUNNAN}

\author{
LI Zong-Shan ${ }^{1}$ TANG Jian-Wei ${ }^{1}$ Z ZHENG Zheng ${ }^{1} \quad$ LI Qing-Jun ${ }^{1} \quad$ LUO Cheng-Kun ${ }^{2}$ LIU Zheng-An ${ }^{2}$ \\ LI Zi-Neng ${ }^{2}$ DUAN Wen-Yong ${ }^{2}$ and GUO Xian-Ming ${ }^{2}$
}

(1 Tropical Rainforest Ecosystem Station, Xishuangbanna Tropical Botanical Garden, Chinese Academy of Sciences , Mengla , Yunnan 666303 , China) (2 Xishuangbanna Bureau of National Nature Reserve , Jinghong , Yunnan 666300 , China)

\begin{abstract}
Tropical montane rain forest (TMRF), one of the primary forest vegetation types in Xishuangbanna, occurs at lower altitude in the north (TMRF I) and higher altitude in the south (TMRF II). In order to understand the plant diversity characteristics of tropical montane rain forests in different zones, six permanent plots $(50 \mathrm{~m} \times 50 \mathrm{~m})$ of tropical montane rain forest communities at different sites in Xishuangbanna were established , two of which were in the TMRF I and four in the TMRF II. The grid method $(10 \mathrm{~m} \times 10 \mathrm{~m})$ was used to record all individuals with a $D B H$ greater than $2.0 \mathrm{~cm}$ in each plot. Shrub and herb species were investigated in nine $5 \mathrm{~m} \times 5 \mathrm{~m}$ and $2 \mathrm{~m} \times 2 \mathrm{~m}$ sub-quadrats, respectively. Plant diversity indices of trees, shrubs, herbs, and three sub-tree layers, and changes in plant diversity indices of communities along the altitudinal gradient were analyzed. The results showed that the total number of plant species in the TMRF communities were $99-181$, tree species richness $(S)$ was $54-113$, Shannon-Wiener diversity $\left(H^{\prime}\right)$ was 1.6487 4.0491 , Simpson index $(\lambda)$ was $0.5035-0.9695$ and Pielou's evenness index $\left(J_{\mathrm{sw}}\right)$ was $0.4133-$ 0.8549 . For shrubs, $S$ was $35-89, H^{\prime}$ was $2.4132-3.7162, \lambda$ was $0.7627-0.9582$, and $J_{\text {sw }}$ was $0.6788-0.8593$. For the herbs, $S$ was $31-65, H^{\prime}$ was $2.7921-3.4992, \lambda$ was $0.9020-0.9382$, and $J_{\mathrm{sw}}$ was $0.7293-0.8382$. The diversity indices, $H^{\prime}, \lambda$, and $J_{\mathrm{sw}}$, were greatest in the herb layer followed by shrubs and then trees, whereas species richness showed no obvious differences in the TMRF I. For TMRF II , the species richness and diversity indices,$H^{\prime}$ and $\lambda$, were greatest in the tree layer followed by the
\end{abstract}


shrub layer and then the herb layer, but the evenness index $\left(J_{\mathrm{sw}}\right)$ was not different among the three layers. The species richness, diversity indices and evenness index of the tree layer and shrub layer in TMRF II communities were higher than those in TMRF I communities, most likely due to the superior habitat of the TMRF II communities. Along the altitudinal gradient, all indices $\left(S, H^{\prime}, \lambda, J_{\mathrm{sw}}\right)$ were greatest at the mid-altitudinal zone (about $1200-1220 \mathrm{~m}$ ) for trees. This can be attributed to the fact that TMRF communities in the mid-altitudinal zone are situated in a ravine area and have the most favorable growing conditions among the six plots. Furthermore, these communities are very near to the seasonal rain forest at lower altitudes, and thus the tropical rain forest plants are very abundant at these altitudes.

Key words Plant diversity, Tropical montane rain forest , Xishuangbanna

热带雨林是地球上的生物多样性中心, 是最为 复杂的森林生态系统, 对人类社会的可持续发展有 重大的意义和价值。但随着人类生产经济活动的不 断扩大，热带森林正以惊人的速度消失，这也使得热 带雨林生物多样性的物种组成、维持机制、保护措施 等相关问题备受人们关注 (Enrlich \& Wilson , 1991； 陈灵芝等, 1997) ,并已成为国际上研究的热点, 如关 于热带雨林生物多样性维持机制的相关假说与理论 的讨论 (Connell , 1978 ; Wright ,2002)，外界干扰因子 如干旱对热带雨林生物多样性影响的分析 (Potts , 2003 ) 林窗动态与热带雨林生物多样性维持关系的 探讨 (Schnitzer \& Carson，2001)，以及对热带雨林树 种分布格局 (Pitman et al . , 1999) 和物种-面积、物种个体数间关系的研究 (Condit et al. , 1996) 等。纵观 当今国际上对热带森林生物多样性的研究, 正在向 长期性、大尺度、全球性的方向发展, 在全球的热带 地区，一系列长期定位观测的大尺度样地(大部分约 $\left.50 \mathrm{hm}^{2}\right)$ 已经建立并开展了大量的观测和研究工作

(Condit et al ., 1996 ; Harms et al . , 2001 ; Lieberman \& Lieberman，1996)。而在我国热带地区这种大样 地、全方位的热带森林植物多样性的研究还非常缺 乏。

山地雨林是我国热带山地垂直带上的一种植被 代表类型, 主要分布于海南岛和云南南部。它是热 带雨林向亚热带森林过渡的一种湿润性森林, 以热 带性成分为主, 并有亚热带成分混生 林下热带成分 占有显著地位, 其组成种类、外貌和结构仍具有热带 雨林的各种基本特征, 已较为逊色, 但仍然属于热带 雨林的范畴 ( 吴征镒, 1980;1987) , 具有重要的生物 多样性保护和科研价值。西双版纳北部地区的热带 山地雨林分布海拔较低, 约为 $850 \sim 1000 \mathrm{~m}$, 具有季 节雨林向北部普洱、思茅一带季风常绿阔叶林的过 渡特征; 而西双版纳南部地区的热带山地雨林大多 分布在局部受逆温影响的山地, 分布海拔较高, 可上 升到 $1500 \sim 1800 \mathrm{~m}$, 具有季节雨林向低山季风常绿
阔叶林的过渡特征 (金振洲等,1997)。在本次研究 中分布在澜沧发展河乡的热带山地雨林由于受顺沟 谷上升的逆温气候的影响, 其分布范围已上升到 $1900 \sim 1970 \mathrm{~m}$ 。由于西双版纳的热带雨林是东南 亚热带雨林的北缘类型，在纬度、温度和海拔都已到 达了热带雨林分布的极限, 且呈断续的小块片存在 于生境条件比较优越的低丘和谷底的局部生境, 与 山地的季风常绿阔叶林和其它森林类型形成了交错 镶嵌的分布格局(朱华等,2000)。然而随着人为干 扰和破坏的不断加剧，热带山地雨林也因不断遭到 破坏而导致分布面积不断缩小。山地雨林作为低地 热带雨林在高海拔的一种变型, 本身就具有分布范 围狭窄和森林生态系统脆弱的特点, 比季节雨林和 季风常绿阔叶林更易受人为干扰和环境因子恶化的 影响而发生退化。作为群落生态组织水平独特且可 测定的植物多样性特征, 能够反映群落的结构类型、 组织水平、发展阶段、稳定程度、生境差异等 (马克 平，1994）, 因此对西双版纳的热带山地雨林开展群 落植物多样性研究及其它的相关研究, 为本地区热 带山地雨林的生物多样性保护提供可靠的科学依据 有着重要的实践价值和深远的现实意义。

纵观国内对热带雨林的研究，我国学者在海南 岛开展的工作较多, 如对热带山地雨林的植物物种 多样性(安树青等,1999; 胡玉佳等,2000; 王峥峰等, 1999 蔵润国等,2001)、物种-个体的相互关系(余世 孝等 ,2001)、森林循环和林隙更替(留润国等,2002) 以及植物物种关联度的研究 (黄世能等,2000) 等。 而对西双版纳热带雨林的研究, 主要集中在海拔较 低的季节雨林、季雨林及与其有密切关系的次生植 被, 如对热带森林的群落学调查 (吴邦兴, 1988; 朱 华等，1998a)、植物区系特征与亲缘关系(Zhu，1997； 朱华等，2001）、植被类型多样性和生态结构多样性 特征(金振洲,1997; 金振洲等,1997) 和热带雨林树 种多样性特征的比较分析 (Cao \& Zhang ,1997) , 以及 先锋群落的树种多样性、结构特征和演替规律 (林露 
湘等 , 2002 唐建维等 , 1997; 1999 ,2003)、外界干扰因 素对热带森林的植物多样性的影响 (施济普等, 2002)，同时对热带雨林种群配置(苏文华，1997) 和 种群动态与稳定性 ( 党承林等, 1997a) 也进行了探 讨。但对西双版纳热带山地雨林开展的研究仅见其 群落类型多样性以及生态结构多样性的初步探讨 (金振洲等 ,1997)、预宋地区山地雨林群落结构和区 系成分的基础分析(王洪等,2001) 以及普文地区山 地雨林建群种种群动态的初步研究 (党承林等, 1997b) 等。由此可见西双版纳的热带山地雨林还缺 乏较为系统、深入的研究, 而把西双版纳热带山地雨 林作为整体研究对象, 在其分布区域设置多个样地 对其植物多样性特征进行全面、系统的研究还未见 报道。

为较深入地掌握和了解西双版纳热带山地雨林 的群落植物多样性特征及其随海拔梯度变化的规 律 , 我们于 2003 年 $2 \sim 4$ 月，在西双版纳的 5 个不同 地点建立了 6 块山地雨林定位样地, 其中低海拔带 上的山地雨林 2 块,高海拔带上的山地雨林 4 块。 本文仅对这 6 块样地的群落植物物种丰富度和植物 多样性特征进行分析，以期为西双版纳地区热带山 地雨林群落的植物多样性保护提供科学依据。并试 图在以下方面进行探索 :1) 山地雨林群落的物种丰 富度 2)山地雨林群落乔木层、灌木层和草本层的植 物多样性特征以及乔木层组成的树种多样性特征; 3) 山地雨林群落的植物多样性特征随海拔梯度变化 的规律。

\section{1 研究地区概况}

研究地点位于西双版纳傣族自治州 $\left(21^{\circ} 09^{\prime} \sim\right.$ $\left.22^{\circ} 36^{\prime} \mathrm{N}, 99^{\circ} 58^{\prime} \sim 101^{\circ} 50^{\prime} \mathrm{E}\right)$ 及其附近地区, 该地区
与老挝、缅甸接壤，西、北、东三面与滇西南山原、山 地相连, 属于横断山系南端无量山脉和怒山山脉余 脉的山原和山地(朱华等,2001)。该地区气候属西 南热带季风气候，干、湿季节变化明显，一年可分干 热湿热和雾凉 3 季, $3 \sim 5$ 月为干热季, 气温较高, 雨量少; $6 \sim 10$ 月为雨季，气候湿热，85\%的雨水集 中于此时期; 11 月至次年 2 月为雾凉季, 降雨量较 少, 但早晚浓雾弥漫, 空气湿度较大, 可弥补此时期 降雨量的不足。该地区的年平均气温为 $20.5{ }^{\circ} \mathrm{C}$, 年 平均降雨量达 $1723.6 \mathrm{~mm}$ 。

\section{2 研究方法}

\section{1 样地的建立及调查方法}

为较全面地反映西双版纳热带山地雨林的植物 多样性特征, 在 5 个不同的地点选取了森林群落发 育较好、结构完整,受人为和自然因素影响较小、坡 度较平缓的山地雨林群落地段建立固定样地。根据 朱华等 (1998b) 对西双版纳热带雨林的研究, 群落的 最适取样面积应为 $2500 \mathrm{~m}^{2}$ 。在本次调查中每块样 地的面积都设为 $2500 \mathrm{~m}^{2}(50 \mathrm{~m} \times 50 \mathrm{~m})$, 其中低海 拔带上的山地雨林设置了 2 块样地, 分布在普文 ( I 号样地)、关坪 (II 号样地) ; 高海拔带上的山地雨林 设置了 4 块样地, 分布在澜沧发展河乡( III 号样地、 IV 号样地)、南贡山 ( $V$ 号样地) 和小腊公路 48 公里 处 (V号样地)。每块样地均观测记录了坡向、坡度、 坡位和海拔等生境因子。土壤为赤红壤或黄棕壤, 土壤深厚, 达 $1 \mathrm{~m}$ 以上。III 号、IV 号样地的枯枝落叶 层和腐殖质较厚, 达 $5 \sim 10 \mathrm{~cm}$, 林内湿度较大, 树干 上附生有较厚的苔藓层; 其它 4 块样地的枯枝落叶 层和腐殖质较薄, 有部分裸露土壤, 林内湿度较小。 各样地的概况详见表 1 。

表 1 西双版纳热带山地雨林样地基本特征

Table 1 The plot characteristics of tropical montane rain forest communities in Xishuangbanna

\begin{tabular}{|c|c|c|c|c|c|c|}
\hline 样地号 Plot No. & I & II & III & IV & $\mathrm{V}$ & VI \\
\hline \multirow{3}{*}{ 地点 Site } & 普文 & 关坪 & 澜沧 & 澜沧 & 南贡山 & 48 公里 \\
\hline & Puwen & Guanping & Lancang & Lancang & Nangongshan & $48 \mathrm{~km}$ \\
\hline & $\begin{array}{l}22^{\circ} 25.705^{\prime} \mathrm{N} \\
100^{\circ} 05.470^{\prime} \mathrm{E}\end{array}$ & $\begin{array}{l}22^{\circ} 13.645^{\prime} \mathrm{N} \\
100^{\circ} 53.280^{\prime} \mathrm{E}\end{array}$ & $\begin{array}{l}22^{\circ} 24.195^{\prime} \mathrm{N} \\
100^{\circ} 11.954^{\prime} \mathrm{E}\end{array}$ & $\begin{array}{l}22^{\circ} 23.542^{\prime} \mathrm{N} \\
100^{\circ} 12.022^{\prime} \mathrm{E}\end{array}$ & $\begin{array}{l}21^{\circ} 37.969^{\prime} \mathrm{N} \\
101^{\circ} 27.735^{\prime} \mathrm{E}\end{array}$ & $\begin{array}{l}21^{\circ} 58.413^{\prime} \mathrm{N} \\
101^{\circ} 09.654^{\prime} \mathrm{E}\end{array}$ \\
\hline 海拔 Elevation (m) & 955 & 970 & 1900 & $1950 \sim 1970$ & $1325 \sim 1345$ & $1200 \sim 1220$ \\
\hline 坡向 Aspect & EN5 & NE40 & NE15 & NE40 & NE40 & NE5 \\
\hline 坡度 Slope $\left({ }^{\circ}\right)$ & $25 \sim 30$ & $5 \sim 10$ & $5 \sim 10$ & $25 \sim 30$ & $15 \sim 20$ & 35 \\
\hline 坡位 & 中下 & 中 & 下 & 上 & 中 & 中 \\
\hline Position & Middle-lower & Middle & Lower & Upper & Middle & Middle \\
\hline 十壤类刑 & 赤红壤 & 赤红壤 & 黄棕壤 & 黄棕壤 & 赤红壤 & 赤红壤 \\
\hline $\begin{array}{l}\text { 土埭天坚 } \\
\text { Soil type }\end{array}$ & $\begin{array}{l}\text { Lateritic red } \\
\text { soil }\end{array}$ & $\begin{array}{l}\text { Lateritic red } \\
\text { soil }\end{array}$ & $\begin{array}{l}\text { Yellow-brown } \\
\text { soil }\end{array}$ & $\begin{array}{l}\text { Yellow-brown } \\
\text { soil }\end{array}$ & $\begin{array}{l}\text { Lateritic red } \\
\text { soil }\end{array}$ & $\begin{array}{l}\text { Lateritic red } \\
\text { soil }\end{array}$ \\
\hline
\end{tabular}


调查时每块样地均被划分为 25 个 $10 \mathrm{~m} \times 10 \mathrm{~m}$ 的样方，对样方内胸径大于等于 $2.0 \mathrm{~cm}$ 以上的乔木 个体进行每木调查, 测量记录植物名称、胸径、高度、 冠幅等, 并挂牌、标号, 同时把每株个体的位置按比 例绘制在坐标图上。在样地纵横两个方向上每隔 1 个 $10 \mathrm{~m} \times 10 \mathrm{~m}$ 的样方设置 1 个 $5 \mathrm{~m} \times 5 \mathrm{~m}$ 的小样 方 (乔木层样方的右下角)共 9 个进行灌木层种类的 调查，对样方中胸径小于等于 $2.0 \mathrm{~cm}$ 、高度大于等于 $1.0 \mathrm{~m}$ 的植株个体观测记录其植物名称、基径、高 度、冠幅等, 并挂牌、标号。草本层种类的调查则在 每个灌木层样方的右下角设置 1 个 $2 \mathrm{~m} \times 2 \mathrm{~m}$ 的小 样方，对样方中高度小于等于 $1 \mathrm{~m}$ 的植株个体测量 记录植物名称、高度、盖度、株(丛)数等, 在本次调查 中未对样地内的附生植物做相关统计。

\section{2 分析方法}

根据物种多样性测度指数应用的广泛程度以及 对群落物种多样性状况的反映能力, 本文选取以下 4 种多样性指数来测度和分析群落物种多样性特征 (马克平, 1994; 冯克平等, 1995)。公式分别为：

(1)物种丰富度 : $S$

(2) Shannon-Wiener 指数: $H^{\prime}=-\sum_{i=1}^{S}\left(\frac{N_{i}}{N}\right) \ln \left(\frac{N_{i}}{N}\right)$

(3) Simpson 指数 : $\lambda=1-\sum_{i=1}^{S} \frac{N_{i}\left(N_{i}-1\right)}{N(N-1)}$

(4) Pielou 均匀度指数 $: J_{\mathrm{sw}}=\frac{H^{\prime}}{\ln (S)}$

式中, $S$ 为样地中的物种总数; $N$ 为 $S$ 个物种全部植 株个体总数; $N_{i}$ 为第 $i$ 个物种的植株个体数。

\section{3 结果与分析}

\section{1 群落的物种丰富度}

根据野外各个样地群落调查资料的整理分析 6 块样地的植物种类组成如表 2 所示。西双版纳山地 雨林群落维管束植物物种为 $99 \sim 181$ 种, 其中乔木 物种为 $56 \sim 137$ 种, 灌木物种为 $5 \sim 9$ 种, 草本物种 为 $12 \sim 21$ 种, 藤本物种为 $2 \sim 15$ 种,蕨类物种为 $3 \sim$
8 种。这表明乔木物种数在群落的物种组成中占绝 对优势, 而灌木种类非常贫乏, 草本物种明显要比灌 木物种丰富。这是因为灌木层绝大多数植株为乔木 层的幼年植株, 而真正的灌木种类很少; 草本层中草 本植物物种较为丰富, 而且乔木幼苗的优势地位已 经显著下降。另外群落中都有较为丰富的藤本植物 和有一定数量的蕨类植物。

\section{2 植物群落各层次的物种多样性}

植物生长型是表征群落外貌特征和垂直结构的 重要指标(马克平等, 1995) , 本文选取最重要的 3 个 类型即乔木、灌木和草本作为研究对象, 对其多样性 进行分析，从空间结构意义来讲，这也是植物群落 3 个最主要的层次。本次调查的各样地群落乔木层大 致可分为上、中、下 3 个层次，乔木上层高度在 $20 \mathrm{~m}$ 以上 胸径在 $30 \mathrm{~cm}$ 以上;乔木中层高度在 $10 \sim 20 \mathrm{~m}$ 之间,胸径在 $10 \sim 30 \mathrm{~cm}$ 之间 ;乔木下层高度在 2 $10 \mathrm{~m}$ 之间，胸径在 2 10 cm 之间。

表 3 显示了西双版纳热带山地雨林群落各个层 次的物种多样性组成。从中可知: 低海拔带上的山 地雨林群落 ( I 号、II 号样地) 不同层次的多样性和 均匀度指数均表现为草本层 > 灌木层 > 乔木层; 而物种丰富度在各层次中则未体现出一定的规律 性, I 号样地表现为乔木层 > 草本层 > 灌木层, 而 II 号样地则表现为草本层 > 乔木层 > 灌木层。 这两块样地乔木层 Shannon-Wiener 指数 $\left(H^{\prime}\right)$ 、Simpson 指数 $(\lambda)$ 和 Pielou 均匀度指数 $\left(J_{\mathrm{sw}}\right)$ 均明显低于 灌木层和草本层, 这是因为乔木层的优势物种突出, 大大降低了各物种间的均匀度。如 I 号样地乔木层 个体数在 10 株以上的物种仅为 5 种, 而窄序崖豆树 (Millettia leptobotrya) 在群落中又占有绝对优势, 其 个体数达 459 ,占乔木总个体数的 $70.18 \%$, 这使其 各多样性指数 $\left(H^{\prime} 、 \lambda 、 J_{\mathrm{sw}}\right)$ 在所有样地中均达到了 最低水平，指数值仅分别为 $1.6487 、 0.5035$ 、 0.4133 ; II 号样地乔木层个体数在 10 株以上 的物种仅为 7 种, 其中窄序崖豆树和睫毛粗叶木

表 2 西双版纳热带山地雨林群落的植物物种组成

Table 2 The plant species composition of tropical montane rain forest communities in Xishuangbanna

\begin{tabular}{|c|c|c|c|c|c|c|}
\hline $\begin{array}{l}\text { 样地号 } \\
\text { Plot No. }\end{array}$ & $\begin{array}{c}\text { 物种总数 } \\
\text { No. of species }\end{array}$ & $\begin{array}{l}\text { 乔木种数 } \\
\text { No. of tree }\end{array}$ & $\begin{array}{l}\text { 灌木种数 } \\
\text { No. of shrub }\end{array}$ & $\begin{array}{l}\text { 草本种数 } \\
\text { No. of herb }\end{array}$ & $\begin{array}{l}\text { 藤本种数 } \\
\text { No. of liana }\end{array}$ & $\begin{array}{l}\text { 蕨类种数 } \\
\text { No. of fern }\end{array}$ \\
\hline I & 99 & 56 & 6 & 21 & 10 & 6 \\
\hline II & 127 & 87 & 5 & 16 & 15 & 4 \\
\hline III & 106 & 73 & 7 & 12 & 9 & 5 \\
\hline IV & 103 & 69 & 6 & 15 & 5 & 8 \\
\hline V & 138 & 88 & 9 & 18 & 10 & 3 \\
\hline VI & 181 & 137 & 8 & 20 & 11 & 5 \\
\hline
\end{tabular}


表 3 西双版纳热带山地雨林群落各层次的物种丰富度、多样性、均匀度指数

Table 3 Species richness, diversity and evenness indices of different layers in the tropical montane rain forest communities in Xishuangbanna

\begin{tabular}{|c|c|c|c|c|c|c|}
\hline \multirow{2}{*}{$\begin{array}{l}\text { 样地号 } \\
\text { Plot No. }\end{array}$} & \multirow{2}{*}{$\begin{array}{l}\text { 层次 } \\
\text { Layer }\end{array}$} & \multirow{2}{*}{$\begin{array}{c}\text { 植株数 } \\
\text { No. of } \\
\text { individuals }\end{array}$} & \multirow{2}{*}{$\begin{array}{c}\text { 物种数 } \\
\text { No. of species }\end{array}$} & \multicolumn{2}{|c|}{$\begin{array}{c}\text { 多样性指数 } \\
\text { Diversity indices }\end{array}$} & \multirow{2}{*}{$\begin{array}{c}\begin{array}{c}\text { 均匀度指数 } \\
\text { Evenness indices }\end{array} \\
J_{\mathrm{sw}}\end{array}$} \\
\hline & & & & $H^{\prime}$ & $\lambda$ & \\
\hline \multirow{6}{*}{ I } & 乔木 Tree & 654 & 54 & 1.6487 & 0.5035 & 0.4133 \\
\hline & 上层 Upper layer & 22 & 14 & 2.5394 & 0.9132 & 0.9622 \\
\hline & 中层 Middle layer & 124 & 28 & 1.7890 & 0.5956 & 0.5369 \\
\hline & 下层 Lower layer & 508 & 36 & 1.3526 & 0.4393 & 0.3774 \\
\hline & 灌木 Shrub & 186 & 35 & 2.4132 & 0.7627 & 0.6788 \\
\hline & 草本 Herb & 360 & 44 & 2.9788 & 0.9208 & 0.7872 \\
\hline \multirow{6}{*}{ II } & 乔木 Tree & 746 & 59 & 2.1808 & 0.7769 & 0.5348 \\
\hline & 上层 Upper layer & 27 & 9 & 1.4794 & 0.6228 & 0.6773 \\
\hline & 中层 Middle layer & 119 & 30 & 2.5272 & 0.8204 & 0.7430 \\
\hline & 下层 Lower layer & 600 & 41 & 1.8235 & 0.7279 & 0.4910 \\
\hline & 灌木 Shrub & 180 & 41 & 2.8066 & 0.8700 & 0.7558 \\
\hline & 草本 Herb & 180 & 65 & 3.4992 & 0.9373 & 0.8382 \\
\hline \multirow{6}{*}{ III } & 乔木 Tree & 641 & 69 & 3.5954 & 0.9588 & 0.8491 \\
\hline & 上层 Upper layer & 39 & 16 & 2.5777 & 0.9126 & 0.9297 \\
\hline & 中层 Middle layer & 119 & 38 & 3.1874 & 0.9400 & 0.8762 \\
\hline & 下层 Lower layer & 483 & 60 & 3.5189 & 0.9552 & 0.8595 \\
\hline & 灌木 Shrub & 471 & 64 & 3.5738 & 0.9582 & 0.8593 \\
\hline & 草本 Herb & 325 & 50 & 3.2624 & 0.9382 & 0.8339 \\
\hline \multirow{6}{*}{ IV } & 乔木 Tree & 776 & 74 & 3.6267 & 0.9606 & 0.8426 \\
\hline & 上层 Upper layer & 21 & 13 & 2.4915 & 0.9116 & 0.9714 \\
\hline & 中层 Middle layer & 124 & 40 & 3.3438 & 0.9524 & 0.9065 \\
\hline & 下层 Lower layer & 631 & 70 & 3.5481 & 0.9561 & 0.8351 \\
\hline & 灌木 Shrub & 342 & 40 & 2.8903 & 0.9159 & 0.7835 \\
\hline & 草本 Herb & 370 & 33 & 2.8246 & 0.9083 & 0.8078 \\
\hline \multirow{6}{*}{ V } & 乔木 Tree & 544 & 93 & 3.7587 & 0.9581 & 0.8293 \\
\hline & 上层 Upper layer & 26 & 13 & 2.3577 & 0.8846 & 0.9192 \\
\hline & 中层 Middle layer & 81 & 34 & 3.1626 & 0.9380 & 0.8969 \\
\hline & 下层 Lower layer & 437 & 83 & 3.6637 & 0.9523 & 0.8291 \\
\hline & 灌木 Shrub & 338 & 55 & 3.2432 & 0.9331 & 0.8093 \\
\hline & 草本 Herb & 331 & 31 & 2.8038 & 0.9193 & 0.8165 \\
\hline \multirow{6}{*}{ VI } & 乔木 Tree & 583 & 113 & 4.0491 & 0.9695 & 0.8549 \\
\hline & 上层 Upper layer & 14 & 9 & 2.1066 & 0.8673 & 0.9587 \\
\hline & 中层 Middle layer & 99 & 38 & 3.3078 & 0.9509 & 0.9093 \\
\hline & 下层 Lower layer & 470 & 103 & 3.9274 & 0.9641 & 0.8474 \\
\hline & 灌木 Shrub & 274 & 89 & 3.7162 & 0.9414 & 0.8279 \\
\hline & 草本 Herb & 335 & 46 & 2.7921 & 0.9020 & 0.7293 \\
\hline
\end{tabular}

(Lasianthus hookeri var. dunniana) 的个体数分别多达 $260 、 220$,分别占总个体数的 $34.85 \% 、 29.49 \%$,优势 物种也比较明显, 这使其各多样性指数 $\left(H^{\prime} 、 \lambda 、 J_{\mathrm{sw}}\right)$ 也较低，指数值分别为 $2.1808 、 0.7769 、 0.5348$ 。而 灌木层中的优势物种多为乔木层树种的幼苗, 但是 物种优势度与乔木层相比有所下降,因而其物种多 样性和均匀度指数有所上升。草本层物种较为丰 富 虽含有一部分乔木层树种的幼苗 ,但已不占优势 地位 ,I 号样地较为常 见的种类有山壳骨 (Pseuderanthemum palatiferum)、爱地草 (Geophila herbacea) 和 黄花胡椒 (Piper flaviflorum)，个体数分别为 59、50、
30 ; II 号样地较为常见的草本种类有柊叶 (Phrynium capitatum)、半肉穗胡椒 (Piper semi-immersum) 和毛九 节( Psychotria pillifera)，个体数仅分别为 $20 、 9 、 6$,除 这些常见物种外, 草本层中其它物种多度大多在 1 $\sim 5$ 株之间。由此可见, 这两块样地草本层物种分 布较为均匀, 无明显的优势物种存在, 因而各多样性 指数 $\left(H^{\prime} 、 \lambda 、 J_{\mathrm{sw}}\right)$ 在群落各层次中达到了最高值, 指 数值分别为 $2.9788 \sim 3.4992 、 0.9208 \sim 0.9373$ 、 $0.7872 \sim 0.8382$ 。

高海拔带上山地雨林群落 ( III 号、IV 号、V 号、VI 号样地)不同层次间的物种丰富度、Shannon-Wiener 
指数和 Simpson 指数均呈现出乔木层 > 灌木层 > 草本层的趋势; Pielou 均匀度指数在群落各层次间 则无一定的规律可循, 在 III 号样地中表现为灌木 层 > 乔木层 > 草本层, 在 IV 号、V 号样地中表现 为乔木层 > 草本层 > 灌木层, 在 VI 号样地中则 表现为乔木层 > 灌木层 > 草本层。这 4 块样地 的群落乔木层的多样性和均匀度指数要高于灌木层 和草本层, 这是因为乔木层的物种丰富度在各层次 中最高, 而且物种间多度分布较为均匀, 无明显的优 势物种存在。其中 VI 号样地群落乔木层物种最为 丰富, 达到了 113 种, 个体数在 10 株以上的物种达 14 种，多度较大的物种有普文楠 (Phoebe puwenensis)、披针叶楠 (Phoebe lanceolata)、粗丝木(Gomphandra tetraandra），个体数仅分别为 $52 、 44 、 37$,可见物种 间分布非常均匀，而仅有 $1 、 2$ 株个体的树种达 58 种占总树种数的 $51.32 \%$, 这使其各多样性指数 $\left(H^{\prime} 、 \lambda 、 J_{\mathrm{sw}}\right)$ 在所有样地中最高, 指数值分别为 $4.0491 、 0.9695 、 0.854$ 9。 III 号、IV 号、V 号样地乔 木层个体数在 10 以上物种数分别达 $12 、 22 、 20,1 、 2$ 株个体的树种数分别达 $23 、 24 、 45$;各样地乔木层也 没有明显的优势物种, 其中 III 号样地多度较大的 物种有疏花臀果木 ( Pygeum laxiflorum) 、粗壮琼楠 (Beilschmiedia robusta)、单叶泡花树 (Meliosma simplicifolia ),IN 号样地较占优势的物种有杯状栲 (Castanopsis calathiformis)、母猪果 (Helicia nilagirica)、刺栲 (Castanopsis hystrix)，V号样地较占优势的物种有湄 公栲 (Castanopsis mekongensis)、椴叶山麻杆 (Alchornea tiliaefolia)、红梗润楠 (Machilus rufipes)，这些物种的 个体数都在 $50 \sim 70$ 左右, 相互之间多度差异较小。 可见这 3 块样地乔木层物种间分布也较为均匀，因 而各多样性指数 $\left(H^{\prime} 、 \lambda 、 J_{\mathrm{sw}}\right)$ 也达到了较高的水平， 指数值分别为 $3.5954 \sim 3.7587 、 0.9581 \sim 0.9606$ 、 $0.8078 \sim 0.8491$ 。 III 号样地灌木层和草本层物种 丰富度仅略低于乔木层, 而且各物种间多度分布非 常均匀, 各多样性指数 $\left(H^{\prime} 、 \lambda 、 J_{\mathrm{sw}}\right)$ 的数值分别达 $3.3 、 0.94 、 0.84$ 左右，基本上与乔木层处于同一水平 上。IV 号、 $\mathrm{V}$ 号、VI号样地灌木层和草本层物种丰富 度则要明显小于乔木层, 大多数植株是乔木层树种 的幼苗, 而且其中一部分物种还占有一定的优势, 因 而各多样性指数与乔木层相比均明显偏低。

从群落乔木不同层次的植物多样性特征来看： 低海拔带上山地雨林群落乔木各层次的物种丰富度 的大小顺序为乔木下层 > 乔木中层 > 乔木上层 ; 而多样性和均匀度指数则无一定的变化规律, 其中
I 号样地乔木各层次的多样性和均匀度指数的大小 顺序为乔木上层 > 乔木中层 > 乔木下层 , II 号样 地乔木各层次的多样性指数的大小顺序为乔木中层 $>$ 乔木下层 > 乔木上层, 均匀度指数则表现为乔 木中层 > 乔木上层 > 乔木下层。I 号样地乔木 上层的多样性和均匀度指数 $\left(H^{\prime} 、 \lambda 、 J_{\mathrm{sw}}\right)$ 数值分别 达 $2.5394 、 0.9132 、 0.9622$, 不仅要远远大于乔木 中、下层, 甚至接近或高于高海拔带上山地雨林的乔 木上层相应指数。这是因为 I 号样地乔木上层中 $1 、 2$ 株个体的树种有 12 种，占物种总数的 $85.71 \%$ ， 其余 2 种为小果栲 (Castanopsis fleuryi) 和山韶子 (Nephelium chryseum) ,个体数目也仅有 3 株, 可见物 种间多度分布相当均匀, 因而各指数值较高; 而乔木 中层、下层则优势物种较为明显, 如窄序崖豆树在中 层、下层的个体数分别为 78 、379 ,占所在层次个体 总数的 $62.90 \%$ 、74.61\% , 使这两个层次的多样性和 均匀度指数明显下降。II 号样地乔木上层的多样性 和均匀度指数 $\left(H^{\prime} 、 \lambda 、 J_{\mathrm{sw}}\right)$ 数值仅分别为 1.4794 、 $0.6228 、 0.6773$, 在 6 块样地中达到了最低水平, 这 是因为本层物种数仅为 9 种, 且山白兰 (Paramichelia baillonii) 又占有绝对优势, 个体数达 16 , 相对多度 为 $59.26 \%$ 其它均为 1.2 株个体的树种, 大大降低 了各物种间的均匀性 ;乔木下层中的窄序崖豆树、眏 毛粗叶木、披针叶楠个体数分别达 211、219、70 其它 物种的个体数都很少, 使得物种间分布很不均匀, 因 而多样性和均匀度指数也偏低; 乔木中层物种较为 丰富且物种间多度分布均匀, 多度较大的窄序崖豆 树、披针叶楠的植株个体数仅分别为 $47 、 12$, 远没有 乔木上层和下层的物种优势度明显，因而本层次的 多样性和均匀度指数最高。

高海拔带上山地雨林群落乔木各层次的各种植 物多样性特征表现出一定的变化规律性, 其中物种 丰富度和多样性指数均表现为乔木下层 > 乔木中 层 > 乔木上层 均匀度指数则表现为乔木上层 > 乔木中层 > 乔木下层。这 4 块样地的乔木上层的 均匀度指数都在 0.90 以上, 明显高于乔木中、下层， 这是因为其没有明显的优势种, 物种间多度比较平 均, 特别是 $\mathrm{IV}$ 号样地的乔木上层除了滇马蹄果 (Protium yunnanense) 有个体数为 3 外, 其余都为 $1 、 2$ 株个体的树种, 使其均匀度指数达 0.9714 , 在所有 样地中最高。4 块样地的乔木下层物种要比乔木 中、上层丰富得多, 而多样性指数又对物种丰富度比 较敏感, 因此乔木下层的多样性指数要高于乔木上 层和中层; 但乔木下层的优势种与乔木上层和中层 
相比又十分明显, 如 III 号样地的疏花臀果木, IV 号 样地的母猪果、杯状栲、三桠苦 (Evodia lepta), V 号 样地的湄公栲、椴叶山麻杆、红梗润楠，VI 号样地 的普文楠、粗丝木, 这些物种的多度都较大, 大大降 低了物种间的均匀度, 而使乔木下层均匀度又低于 乔木上层和中层。

从表 3 中还可以看出: 高海拔带上山地雨林群 落 ( III 号、IV号、V 号、VI号样地)乔木层、灌木层的物 种丰富度, 多样性和均匀度指数均明显大于低海拔 带上山地雨林 ( I 号、II 号样地) , 尤以乔木层更加突 出, 其次是灌木层; 而两种海拔带上山地雨林草本层 的各指数值没有明显差异。另外, 高海拔带上山地 雨林群落的乔木中层、下层的物种丰富度以及多样 性和均匀度指数均要明显大于低海拔带上的山地雨 林乔木中、下层, 尤以乔木下层表现得最为突出, 其 次是乔木中层; 而两种海拔带上山地雨林乔木上层 的各指数值没有明显差异。

由以上分析可知 :西双版纳热带山地雨林群落 乔木层的物种丰富度 $(S)$ 为 $54 \sim 113$,Shannon-Wiener 指数 $\left(H^{\prime}\right)$ 为 $1.6487 \sim 4.0491$,Simpson 指数 $(\lambda)$ 为 $0.5035 \sim 0.9695$,Pielou 均匀度指数 $\left(J_{\mathrm{sw}}\right)$ 为 0.4133 $\sim 0.854$ 9。灌木层的 $S$ 为 $35 \sim 89, H^{\prime}$ 为 $2.4132 \sim$ $3.7162, \lambda$ 为 $0.7627 \sim 0.9582, J_{\mathrm{sw}}$ 为 $0.6788 \sim$ 0.8593 。草本层的各种指数值为 $: S$ 为 $31 \sim 65, H^{\prime}$ 为 $2.7921 \sim 3.4992, \lambda$ 为 $0.9020 \sim 0.9382, J_{\mathrm{sw}}$ 为 $0.7293 \sim 0.8382$ 。

\section{3 群落植物多样性特征随海拔梯度的变化规律}

山地植被群落植物多样性随海拔高度的变化规 律一直是生态学家关注的问题,一般认为在群落物 种多样性的空间分布格局中, 物种多样性随海拔梯 度变化是极为显著的(马克平等,1995)。本次调查 着重探讨山地雨林群落乔木层、灌木层、草本层的植 物多样性特征随海拔梯度的变化规律。

群落乔木层的物种丰富度 $(S)$ 和 ShannonWiener 指数 $\left(H^{\prime}\right)$ 随海拔的升高呈现出先上升后下 降的趋势 (表 4), 在中等海拔高度 VI号样地(海拔为 $1200 \sim 1220 \mathrm{~m}$ ) 处达到最大值, 其中 $S$ 为 $113 、 H^{\prime}$ 为 4.0491 ; 而在海拔较低的 I 号、II 号样地 (海拔为 950 975 m) 以及海拔较高的 III 号、 IV 号样地 (海拔 为 $1900 \sim 2000 \mathrm{~m}$ ) 指数值较低。Simpson 指数和 Pielou 均匀度指数则随着海拔的升高首先快速上 升, 也是在 VI 号样地处达到最高值, 指数值分别为 0.969 5、0.854 9, 后呈波浪式缓慢地下降。灌木层 的物种丰富度、多样性和均匀度指数随海拔梯度的
变化, 分别在中等海拔 VI 号样地(海拔为 1200 $1220 \mathrm{~m}$ ) 和较高海拔 III 号地 (海拔为 $1900 \mathrm{~m}$ ) 处指 数值达到了较高的水平, 而在其它样地中指数值较 低。草本层植物多样性特征随海拔梯度的变化也呈 现出一致的变化趋势 物种丰富度、多样性和均匀度 指数在较低海拔 II 号样地 (海拔为 $975 \mathrm{~m}$ ) 和较高海 拔 III 号样地(海拔为 $1900 \mathrm{~m}$ ) 处达到了较高的水平， 而在其它样地中指数值较低。从表 4 中还可以看 出: 乔木层的物种丰富度、多样性和均匀度指数随海 拔梯度变化幅度最大, 灌木层各种指数值的变化幅 度与乔木层相比已经明显减小, 而草本层各种指数 值的变化幅度最小。

\section{4 结论与讨论}

1) 低海拔带上的山地雨林乔木层、灌木层以及 乔木中层、下层的物种丰富度、多样性和均匀度指数 均明显低于高海拔带上的山地雨林相应层次, 出现 这种植物多样性特征的原因是因为低海拔带上的山 地雨林分布于西双版纳的北部地区，温度和热量都 较低, 水湿条件也不是十分优越, 使得群落中少数物 种充分发展, 而致使群落乔木层和灌木层的物种优 势度十分明显; 而草本层由于受乔木层和灌木层荫 蔽,使外界不利因素的影响大大减弱,局部小生境比 较优越, 许多热带雨林林下成分大量出现, 而且物种 间的植株数目较为均匀, 因而多样性指数和均匀度 又较高。高海拔带上的山地雨林乔木层、灌木层以 及乔木中层、下层的各指数值与低海拔带上山地雨 林相比均偏高, 这是因为高海拔带上的山地雨林分 布于西双版纳南部山地, 温度较高, 水湿条件较好, 生境条件比低海拔带上的山地雨林要更加优越, 生 境条件优越则多样性指数就高, 这可能是一个普遍 的规律 (彭少麟等, 1983; 朱守谦, 1987)。其群落不 同层次的物种丰富度和多样性指数也呈现出基本一 致的规律, 表现为乔木层 > 灌木层 > 草本层, 黄 建辉等 (1997) 在中国地带性森林群落物种多样性的 比较研究中也指出热带地区群落的乔木层的物种丰 富度和多样性为最高。群落乔木各层的植物多样性 也呈现出一致的变化趋势, 物种丰富度与多样性指 数表现为乔木下层 > 乔木中层 > 乔木上层 ,可见 乔木下层的物种丰富度和多样性指数均显著大于乔 木中、上层, 彭少麟等 (1983)、朱守谦 (1987) 和曹铁 如等 (1997) 在亚热带常绿阔叶林植物多样性研究中 指出群落的乔木下层的物种丰富度和多样性要高于 乔木上层, 这可能是亚热带森林生态系统的普遍规 
表 4 西双版纳热带山地雨林群落乔木层、灌木层、草本层植物多样性特征随海拔梯度的变化

Table 4 The variation of plant diversity characteristics of tree, shrub and herb layers in tropical montane rainforest communities with altitudinal gradient in Xishuangbanna

\begin{tabular}{|c|c|c|c|c|c|c|c|}
\hline \multirow{2}{*}{$\begin{array}{l}\text { 层次 } \\
\text { Layer }\end{array}$} & \multirow{2}{*}{$\begin{array}{c}\text { 海拔 (m) } \\
\text { Altitude }\end{array}$} & \multirow{2}{*}{$\begin{array}{l}\text { 样地号 } \\
\text { Plot No. }\end{array}$} & \multirow{2}{*}{$\begin{array}{c}\text { 植株数 } \\
\text { No. of } \\
\text { individuals }\end{array}$} & \multirow{2}{*}{$\begin{array}{l}\text { 物种数 } \\
\text { No. of } \\
\text { species }\end{array}$} & \multicolumn{2}{|c|}{$\begin{array}{c}\text { 多样性指数 } \\
\text { Diversity indices }\end{array}$} & \multirow{2}{*}{$\begin{array}{c}\begin{array}{c}\text { 均匀度指数 } \\
\text { Evenness indices }\end{array} \\
J_{\mathrm{sw}}\end{array}$} \\
\hline & & & & & $H^{\prime}$ & $\lambda$ & \\
\hline \multirow{6}{*}{$\begin{array}{c}\text { 乔木层 } \\
\text { Tree }\end{array}$} & 955 & I & 654 & 54 & 1.6487 & 0.5035 & 0.4133 \\
\hline & 970 & II & 746 & 59 & 2.1808 & 0.7769 & 0.5348 \\
\hline & $1200 \sim 1220$ & VI & 583 & 113 & 4.0491 & 0.9695 & 0.8549 \\
\hline & $1325 \sim 1345$ & V & 544 & 93 & 3.7587 & 0.9581 & 0.8293 \\
\hline & 1900 & III & 641 & 69 & 3.5954 & 0.9588 & 0.8491 \\
\hline & $1950 \sim 1970$ & IV & 776 & 74 & 3.6267 & 0.9606 & 0.8426 \\
\hline \multirow{6}{*}{$\begin{array}{l}\text { 灌木层 } \\
\text { Shrub }\end{array}$} & 955 & I & 186 & 35 & 2.4132 & 0.7627 & 0.6788 \\
\hline & 970 & II & 180 & 41 & 2.8066 & 0.8700 & 0.7558 \\
\hline & $1200 \sim 1220$ & VI & 274 & 89 & 3.7162 & 0.9414 & 0.8279 \\
\hline & $1325 \sim 1345$ & V & 338 & 55 & 3.2432 & 0.9331 & 0.8093 \\
\hline & 1900 & IIII & 471 & 64 & 3.5738 & 0.9582 & 0.8593 \\
\hline & $1950 \sim 1970$ & IV & 342 & 40 & 2.8903 & 0.9159 & 0.7835 \\
\hline \multirow{6}{*}{$\begin{array}{c}\text { 草本层 } \\
\text { Herb }\end{array}$} & 955 & I & 360 & 44 & 2.9788 & 0.9208 & 0.7872 \\
\hline & 970 & II & 180 & 65 & 3.4992 & 0.9373 & 0.8382 \\
\hline & $1200 \sim 1220$ & VI & 335 & 46 & 2.7921 & 0.9020 & 0.7293 \\
\hline & $1325 \sim 1345$ & V & 331 & 31 & 2.8038 & 0.9193 & 0.8165 \\
\hline & 1900 & III & 325 & 50 & 3.2624 & 0.9382 & 0.8339 \\
\hline & $1950 \sim 1970$ & IV & 370 & 33 & 2.8246 & 0.9083 & 0.8078 \\
\hline
\end{tabular}

律 这种多样性特征与本次研究结果是相一致的。 均匀度指数则表现为乔木上层 > 乔木中层 > 乔 木下层, 乔木上层拥有最高的均匀度, 这说明了其中 优势物种不明显，物种间多度趋于均匀 种间相互竞 争减少并且发展了复杂的相互关系, 种群配置更为 合理, 向着互利共存的方向发展。从各个方面的植 物多样性特征都可以看出, 高海拔带上的山地雨林 群落是一种发育较为成熟的热带山地雨林。

2) 西双版纳的热带山地雨林群落乔木层的物 种丰富度、多样性和均匀度指数均在中等海拔高度 地带 (海拔为 $1200 \sim 1220 \mathrm{~m}$ ) 达到最高值, 这种现象 即称为 中间高度膨胀 (Mid-altitude bulge)" 现象, 国 内外许多研究也得出了这种植物物种多样性随海拔 梯度的变化规律 (谢晋阳等, 1994; 奚为民, 1997; Whittaker, 1960)。其中的原因是中等海拔高度地带 的山地雨林分布于西双版纳南部地区沟谷地带, 温 度、水湿条件以及其它生境因子在所有调查样地中 最为优越; 而且中等海拔带上的山地雨林与低地季 节雨林间的距离较近, 这使得山地雨林群落中的季 节雨林成分十分丰富, 这便大大增加了群落的物种 丰富度。

3) 西双版纳山地雨林群落的植物多样性特征 与其它地区的森林群落相比 (表 5), 低海拔带上山
地雨林的 Shannon-Wiener 指数和 Pielou 均匀度指数 的平均值仅高于生境比较恶劣的西双版纳石灰山季 雨林, 而低于广东鼎湖山常绿阔叶林和西双版纳的 季风常绿阔叶林。高海拔带上的山地雨林的 Shannon-Wiener 指数和 Pielou 均匀度指数的平均值要明 显高于西双版纳季风常绿阔叶林和广东鼎湖山亚热 带常绿阔叶林, 而且与西双版纳低地的热带季节雨 林的指数值已十分接近。高海拔带上山地雨林的 Shannon-Wiener 指数的平均值要低于低纬度地区巴 西、哥斯达黎加以及马来半岛的热带雨林, 也要低于 海南岛的热带山地雨林。低纬度地区热带雨林的 Shannon-Wiener 指数较高, 说明其生境比山地雨林更 为优越, 物种也远比山地雨林丰富, 海南岛热带山地 雨林的物种是十分丰富的, 其物种丰富度以及 Shannon-Wiener 指数甚至高于海南岛、西双版纳的低地 雨林(朱华等, 2002)。虽然, 各种不同地区热带森林 的 Shannon-Wiener 指数之间有着很大的差异, 但是 Pielou 均匀度指数均较高, 都明显地大于亚热带常 绿阔叶林和西双版纳季风常绿阔叶林, 而且指数值 在不同地区热带雨林之间的差异较小, 这说明了这 些森林群落的物种优势度都很小。

4）虽然本项研究较全面地反映了西双版纳热 带山地雨林群落的植物多样性特征, 但因受各种条 
表 5 西双版纳热带山地雨林群落植物多样性和均匀度指数与其它森林群落的比较

Table 5 Comparisons of tree species diversity and evenness indices between tropical montane rain forests in Xishuangbanna and the other forest communities

\begin{tabular}{|c|c|c|c|c|c|c|c|c|c|c|}
\hline $\begin{array}{l}\text { 序号 } \\
\text { Order }\end{array}$ & $\begin{array}{l}\text { 群落名称 } \\
\text { Community }\end{array}$ & $\begin{array}{l}\text { 地点 } \\
\text { Location }\end{array}$ & $\begin{array}{c}\text { 海拔 } \\
\text { Altitude }(\mathrm{m})\end{array}$ & $\begin{array}{l}\text { 面积 } \\
\text { Area } \\
\left(\mathrm{m}^{2}\right)\end{array}$ & $\begin{array}{c}\text { 胸径 }(D B H) \\
\text { Diameter at } \\
\text { breast height } \\
(\mathrm{cm})\end{array}$ & $\begin{array}{c}\text { 植株数 } \\
\text { No. of } \\
\text { individuals }\end{array}$ & $\begin{array}{l}\text { 物种数 } \\
\text { No. of } \\
\text { species }\end{array}$ & $\begin{array}{c}\begin{array}{c}\text { 多样性指数 } \\
\text { Diversity } \\
\text { indices }\end{array} \\
H^{\prime}\end{array}$ & $\begin{array}{c}\begin{array}{c}\text { 均匀度指数 } \\
\text { Evenness } \\
\text { indices }\end{array} \\
J_{\mathrm{sw}}\end{array}$ & $\begin{array}{c}\text { 引用文献 } \\
\text { References } \\
\text { cited }\end{array}$ \\
\hline 1 & $\begin{array}{c}\text { 热带雨林 } \\
\text { TRF }\end{array}$ & $\begin{array}{c}\text { 哥斯达黎加 } \\
\text { Costarica }\end{array}$ & 300 & 10000 & $\geqslant 10$ & 551 & 149 & 4.508 & 0.901 & $\begin{array}{l}\text { Lieberman \& } \\
\text { Lieberman , } \\
1996\end{array}$ \\
\hline 2 & $\begin{array}{c}\text { 热带雨林 } \\
\text { TRF }\end{array}$ & 巴西 Brazil & & 35000 & $\geqslant 10$ & 1420 & 178 & 6.21 & & \multirow[t]{2}{*}{$\begin{array}{l}\text { 安树青等, } \\
1999\end{array}$} \\
\hline 3 & $\begin{array}{c}\text { 热带雨林 } \\
\text { TRF }\end{array}$ & $\begin{array}{c}\text { 马来半岛北部 } \\
\text { Northern Malay , } \\
\text { Peninsula }\end{array}$ & & 1600 & $\geqslant 4.5$ & 118 & 59 & 4.52 & & \\
\hline 4 & $\begin{array}{c}\text { 热带雨林 } \\
\text { TRF }\end{array}$ & $\begin{array}{c}\text { 西双版纳 } \\
\text { Xishuangbanna }\end{array}$ & 660 & 2500 & $\geqslant 10$ & 257 & 77 & 3.888 & 0.996 & $\begin{array}{l}\text { Cao \& Zhang, } \\
1997\end{array}$ \\
\hline 5 & $\begin{array}{c}\text { 山地雨林 } \\
\text { TMRF }\end{array}$ & $\begin{array}{c}\text { 海南五指山 } \\
\text { Wuzhi Mountain , } \\
\text { Hainan }\end{array}$ & $820 \sim 870$ & 5000 & $\geqslant 5$ & 671 & 117 & 5.900 & 0.859 & $\begin{array}{l}\text { 安树青等, } \\
1999\end{array}$ \\
\hline 6 & $\begin{array}{c}\text { 山地雨林 } \\
\text { TMRF }\end{array}$ & $\begin{array}{c}\text { 海南吊罗山 } \\
\text { Diaoluo Mountain } \\
\text { Hainan }\end{array}$ & $900 \sim 980$ & 5000 & $\geqslant 5$ & 632 & 118 & 4.195 & 0.880 & $\begin{array}{l}\text { 王峥峰等， } \\
1999\end{array}$ \\
\hline 7 & $\begin{array}{l}\text { 山地雨林 } \\
\text { TMRF I }\end{array}$ & $\begin{array}{c}\text { 西双版纳 } \\
\text { Xishuangbanna }\end{array}$ & $955 \sim 970$ & 2500 & $\geqslant 2$ & 700 & 57 & 1.9147 & 0.4741 & \multirow{2}{*}{$\begin{array}{l}\text { 本次调查 } \\
\text { This } \\
\text { investigation }\end{array}$} \\
\hline 8 & $\begin{array}{l}\text { 山地雨林 } \\
\text { TMRF II }\end{array}$ & $\begin{array}{c}\text { 西双版纳 } \\
\text { Xishuangbanna }\end{array}$ & $1210 \sim 1970$ & 2500 & $\geqslant 2$ & 634 & 93 & 3.8115 & 0.8423 & \\
\hline 9 & $\begin{array}{c}\text { 石灰山季雨林 } \\
\text { MFL }\end{array}$ & $\begin{array}{c}\text { 西双版纳 } \\
\text { Xishuangbanna }\end{array}$ & 750 & 400 & $\geqslant 3$ & 150 & 19 & 1.664 & 0.565 & \multirow[t]{2}{*}{$\begin{array}{l}\text { Cao \& Zhang , } \\
1997\end{array}$} \\
\hline 10 & $\begin{array}{c}\text { 常绿阔叶林 } \\
\text { EBLF }\end{array}$ & $\begin{array}{c}\text { 西双版纳 } \\
\text { Xishuangbanna }\end{array}$ & 1050 & 1200 & $\geqslant 5$ & 164 & 29 & 2.802 & 0.832 & \\
\hline 11 & $\begin{array}{c}\text { 常绿阔叶林 } \\
\text { EBLF }\end{array}$ & $\begin{array}{c}\text { 广东鼎湖山 } \\
\text { Dinghu Mountain } \\
\text { Guangdong }\end{array}$ & 250 & 1200 & & & & 2.241 & 0.576 & $\begin{array}{l}\text { 彭少麟等， } \\
1983\end{array}$ \\
\hline
\end{tabular}

TRF : Tropical rain forest TMRF : Tropical montane rain forest TMRF I : Tropical montane rain forest at lower altitude TMRF II : Tropical montane rain forest at higher altitude MFL : Monsoon forest over limestone EBLF : Evergreen broad-leaved forest

件及因素的限制和影响 (如经费、人力和时间等)，在 同一海拔地带所建立的样地数量仍略显不足，如能 在同一海拔地带建立 3 块相等面积的样地, 将会更 加全面、系统地反映西双版纳热带山地雨林群落的 植物多样性特征及其随海拔高度变化的规律。

\section{参 考 文 献}

An, S. Q. (安树青), X. L. Zhu (朱学雷), Z. F. Wang (王 峥峰), D. G. Campbell, G. Q. Li (李国旗) \& X. L. Chen (陈兴龙). 1999. The plant species diversity in a tropical montane rain forest on Wuzhi Mountain, Hainan. Acta Ecologica Sinica (生态学报), 19: 803 809. (in Chinese with English abstract)

Cao, M. \& J. H. Zhang. 1997. Tree species diversity of tropical forest vegetation in Xishuangbanna, SW China. Biodiversity and Conservation, 6: 995 1006.

Cao, T. R. (曹铁如), C. J. Qi (祁承经) \& X. L. Yu (喻勋 林) . 1997. Studies on species diversity of Fagus lucida commu- nities on the Badagongshan Moutain, Hunan. Chinese Biodiversity (生物多样性), 5: 112 120. (in Chinese with English abstract)

Chen, L. Z. (陈灵芝) \& Y. Q. Qian (钱迎倩). 1997. Frontiers in biodiversity science. Acta Ecologica Sinica (生态学报), 17: $565 \sim 572$. (in Chinese with English abstract)

Condit, R., S. Hubbell, J. LaFrnkie, T. Sukumar, N. Manokaran, R. Foster \& P. Ashton. 1996. Species-area and species-individual relationships for tropical trees: a comparison of three $50 \mathrm{hm}^{2}$ plots. Journal of Ecology, 84: 549 562.

Connell, J. H. 1978. Diversity in tropical rain forests and coral reefs. Science, 199: 1302 1310.

Dang, C. L. (党承林) \& B. R. Wang (王宝荣). 1997a. The relationship between tree population dynamics and stability in Menyang Biosphere Reserve of Xishuangbanna. Acta Botanica Yunnanica (云南植物研究), (Suppl. IX) : 77 82. (in Chinese with English abstract)

Dang, C. L. (党承林) \& W. Qian (钱韦). 1997b. A study on the population dynamics of constructive species of the tropical 
montane rain forest in Xishuangbanna. Acta Botanica Yunnanica (云南植物研究), (Suppl. IX) : 83 91. (in Chinese with English abstract)

Ehrlich, P. R. \& E. O. Wilson. 1991. Biodiversity studies: science and policy. Science, 253: $758 \sim 762$.

Harms, K., R. Condit, S. P. Hubbell \& R. B. Foster. 2001. Habitat association of trees and shrubs in a $50-\mathrm{hm}^{2}$ neotropical forest plot. Journal of Ecology, 89: $947 \sim 959$.

Hu, Y. J. (胡玉佳) \& X. Q. Ding (丁小球). 2000. A study on the plant species diversity of tropical natural forest in Bawangling, Hainan Island. Chinese Biodiversity (生物多样性), 8: $370 \sim 377$. (in Chinese with English abstract)

Huang, J. H. (黄建辉)，X. M. Gao (高贤明)，K. P. Ma (马 克平) \& L. Z. Chen (陈灵芝). 1997. A comparative study on species diversity in zonal forest communities. Acta Ecologica Sinica (生态学报), 17: 611 618. (in Chinese with English abstract)

Huang, S. N. (黄世能), Y. D. Li (李意德), T. S. Luo (骆 土寿) \& B. S. Wang (王伯荪). 2000. Dynamics of associations between tree species in a secondary tropical montane rain forest at Jianfengling on Hainan Island. Acta Phytoecologica Sinica (植物生态学报), 24: 569 574. (in Chinese with English abstract)

Jin, Z. Z. (金振洲). 1997. The diversity features of the ecological structures of plant species component in the tropical rain forest of Xishuangbanna, Yunnan. Acta Botanica Yunnanica (云南植 物研究), (Suppl. IX) : 31 57. (in Chinese with English abstract)

Jin, Z. Z. (金振洲) \& X. K. Ou (欧晓昆). 1997. The diversity features of plant community types in the tropical rain forest vegetation of Xishuangbanna. Acta Botanica Yunnanica (云南植 物研究), (Suppl. IX ) : 1 30. (in Chinese with English abstract)

Lieberman, D. \& M. Lieberman. 1996. Tropical forest structure and composition on a large scale altitudinal gradient in Costa Rica. Journal of Ecology, 84: $137 \sim 152$.

Lin, L. X. (林露湘)，M. Cao (曹敏)，Y. Tang (唐勇)，X. H. Fu (付先惠) \& J. H. Zhang (张建侯). 2002. Tree species diversity in abandoned swidden fields of Xishuangbanna, SW China. Acta Phytoecologica Sinica (植物生态学报), 26 : 216 222. (in Chinese with English abstract)

Ma，K. P. (马克平)，J. H. Huang (黄建辉)， S. L. Yu (于 顺利) \& L. Z. Chen (陈灵芝). 1995. Plant community diversity in Dongling Mountain, Beijing, China. II . Species richness, evenness and species diversities. Acta Ecologica Sinica (生态学报), 15: 268 277. (in Chinese with English abstract)

Ma, K. P. (马克平) . 1994. The measurement of community diversity. In: Qian, Y. Q. (钱迎倩) \& K. P. Ma (马克平) eds. Principles and methodologies of biodiversity studies. Beijing: China Science and Technology Press. 141 165. (in Chinese)

Peng, S. L. (彭少麟) \& Z. H. Chen (陈章和) . 1983. Species diversity of sub-tropical forest communities in Guangdong. Ecological Science (生态科学), 1: $98 \sim 103$. (in Chinese with English abstract)

Pitman, S. L., J. Terborgh, M. R. Sklman \& P. V. Nunez.
1999. Tree species distributions in an upper Amazonian forest. Ecology, 80: $2651 \sim 2661$.

Potts, M. D. 2003. Drought in a Bornean everwet rain forest. Journal of Ecology, 91: $467 \sim 474$.

Schnitzer, S. \& W. P. Carson. 2001. Treefall gaps and the maintenance of species diversity in a tropical forest. Ecology, 82: 913 $\sim 919$.

Shi, J. P. (施济普) \& H. Zhu (朱华). 2002. Effects of three main disturbance manners on the plant diversity of the tropical forest in Xishuangbanna. Guihaia (广西植物), 22: 129 135. (in Chinese with English abstract)

Su, W. H. (苏文华). 1997. Study on the composition of tree population of Pometia tomentosa community in the tropical seasonal rain forest of Xishuangbanna. Acta Botanica Yunnanica (云 南植物研究), (Suppl. IX ) : $97 \sim 107$. (in Chinese with English abstract)

Tang, J. W. (唐建维), J. H. Zhang (张建侯), Q. S. Song (宋启示) \& Z. L. Feng (冯志立). 1997. Analysis on the characteristics of Millettia laptobotrya community in Xishuangbanna. Guihaia (广西植物), 17: $338 \sim 344$. (in Chinese with English abstract)

Tang, J. W. (唐建维), J. H. Zhang (张建侯), Q. S. Song (宋启示) \& Z. L. Feng (冯志立) . 1999. Community analysis on secondary tropical vegetations in Xishuangbanna. Chinese Journal of Applied Ecology (应用生态学报), 10: 135 139 . (in Chinese with English abstract)

Tang, J. W. (唐建维), J. P. Shi (施济普), G. M. Zhang (张光明), K. J. Bai (白坤甲), X. M. Guo (郭贤明), S. Z. Zhu (朱胜忠), W. G. Duan (段文贵), J. P. Song (宋 军平), J. H. Dao (刀建红) \& J. G. Huang (黄建国). 2003. Successional dynamics and structure characteristics of pioneer Musa acuminata Colla communities in Xishuangbanna, Yunnan. Chinese Biodiversity (生物多样性), 11: 37 46. (in Chinese with English abstract)

Wang, H. (王洪), H. Zhu (朱华) \& B. G. Li (李保贵). 2001. The community study of tropical montane rain forest in Mengsong, Xishuangbanna. Guihaia (广西植物), 21: 303 314. (in Chinese with English abstract)

Wang, Z. F. (王峥峰), S. Q. An (安树青), D. G. Campell, X. B. Yang (杨小波) \& X. L. Zhu (朱学雷). 1999. Biodiversity of the montane rain forest in Diaoluo Mountain, Hainan. Acta Ecologica Sinica (生态学报), 19: 61 67. (in Chinese with English abstract)

Whittaker, R. H. 1960. Vegetation of the Siskiyou Mountains, Oregon and California. Ecological Monographs, 30: $279 \sim 338$.

Wright, S. J. 2002. Plant diversity in tropical forests: a review of mechanism of species coexistence. Oecologia, 130: 1 14 .

Wu, B. X. (吴邦兴). 1988. The features of physiognomy and structure of the seasonal rainforest in Xishuangbanna of Yunnan. Acta Botanica Yunnanica (云南植物研究), 10: 1 10. (in Chinese with English abstract)

Wu, Z. Y. (吴征镒). 1980. Vegetation of China. Beijing: Science Press. 889 916. (in Chinese)

Wu, Z. Y. (吴征镒). 1987. Vegetation of Yunnan. Beijing: Science Press. $97 \sim 192$. (in Chinese)

Xi，W. M. (奚为民). 1997. Study on species diversity of forest in Wuling Mountain Natural Reserve. Chinese Biodiversity (生物 
多样性), 5: 121 125. (in Chinese with English abstract) Xie, J. Y. (谢晋阳) \& L. Z. Chen (陈灵芝). 1994. Species diversity characteristics of deciduous forests in the warm temperate zone of North China. Acta Ecologica Sinica (生态学报), 14: 337 344. (in Chinese with English abstract)

Yu, S. X. (余世孝)，R. G. Zang (藏润国) \& Y. X. Jiang (蒋有绪). 2001. Species richness-abundance relationships in four tropical forests on altitudinal gradient in Bawangling Nature Reserve, Hainan. Acta Phytoecologica Sinica (植物生态学 报), 25: $291 \sim 297$. (in Chinese with English abstract)

Zang, R. G. (藏润国), Y. X. Jiang (蒋有绪) \& S. X. Yu (余世孝). 2002. The forest cycle and tree species diversity dynamics in a tropical montane rain forest of Hainan Island, South China. Acta Ecologica Sinica (生态学报), 22: $24 \sim 32$. (in Chinese with English abstract)

Zang, R. G. (蔵润国)，Y. C. Yang (杨彦承) \& Y. X. Jiang (蒋有绪). 2001. Community structure and tree species diversity characteristics in a tropical montane rain forest in Bawangling Nature Reserve, Hainan Island. Acta Phytoecologica Sinica (植物 生态学报), 25: 270 275. (in Chinese with English abstract) Zhu, H. 1997. Ecological and biogeographical studies of the tropical rain forest of South Yunnan, SW China with a special reference to its relation with rain forests of tropical Asia. Journal of Biogeography, 24: $647 \sim 662$.

Zhu, H. (朱华), Z. F. Xu (许再富), H. Wang (王洪), B. G. Li (李保贵) \& B. Y. Long (龙碧云). 2000. Effects of fragmentation on the structure, species composition and diversity of tropical rain forest in Xishuangbanna, Yunnan. Acta Phytoecologica Sinica (植物生态学报), 24: $560 \sim 568$. (in Chinese with English abstract)

Zhu, H. (朱华), Y. H. Li (李延辉), Z. F. Xu (许再富), H. Wang (王洪) \& B. G. Li (李保贵). 2001. Characteristics and affinity of the flora of Xishuangbanna, SW China. Guihaia (广西植物 ), 21: $127 \sim 136$. (in Chinese with English abstract)

Zhu, H. (朱华) \& H. X. Zhou (周虹霞). 2002. A comparative study on the tropical rain forests in Xishuangbanna and Hainan. Acta Botanica Yunnanica (云南植物研究), 24: 1 13. (in Chinese with English abstract)

Zhu, H. (朱华), H. Wang (王洪), B. G. Li (李保贵) \& Z. F. Xu (许再富). 1998a. Research on the tropical seasonal rainforest of Xishuangbanna, South Yunnan. Guihaia (广西植 物), 18: $371 \sim 384$. (in Chinese with English abstract)

Zhu, H. (朱华), H. Wang (王洪), B. G. Li (李保贵) \& Z. F. Xu (许再富). 1998b. Species diversity of primary tropical rain forest of South Yunnan of China with special reference to sampling area. Chinese Biodiversity (生物多样性), 6: $241 \sim$ 247. (in Chinese with English abstract)

Zhu, S. Q. (朱守谦). 1987. A preliminary study of the species diversity of part of the forest communities in Guizhou. Acta Phytoecologica et Geobotanica Sinica (植物生态学与地植物学丛 刊), 11: $286 \sim 295$. (in Chinese with English abstract) 